\title{
AKTIVITAS ANTIBAKTERI EKSTRAK ISOLAT FUNGI ENDOFIT DARI AKAR MANGROVE (Rhizophora apiculata Blume) SECARA KLT BIOAUTOGRAFI
}

\author{
Fitriana, Eka Nursithya
}

Fakultas Farmasi Universitas Muslim Indonesia, Makassar

Email : fitriana.fitriana@umi.ac.id

\begin{abstract}
Endophytic fungi have the ability to produce bioactive compounds one of which is antibacterial. A search of bioactive compounds in this research are the first was isolated endophytic fungi on the roots of mangrove then be purified and macroscopic order to obtain pure 6 isolates endophytic fungi. Proceed with the screening test to test bacteria and endophytic fungal isolates obtained first by IJM 2 code which provides activity against 5 test bacteria with the formation of the largest inhibition zone diameter. Then proceed with the fermentation of isolates IJM 2 for 21 days at room temperature using Potato Dextrose Broth medium after the separation to obtain a supernatant and mycelia. Then proceed with the solvent extraction using ethyl acetate and the extract obtained extract supernatant and mycelia. The extract obtained is then followed by TLC-Bioautografi testing using the eluent $n$-butanol: acetic acid: water (8: 1: 2). Results chromatogram profile with KLT-Bioutografi method showed antibacterial activity against bacteria Shigella dysentriae, Pseudomonas aeruginosa, Salmonella thypii, Vibrio cholerae, Stahpylococcus aureus.
\end{abstract}

Keywords: Endophytic fungi, antibacterial, Rhizophora apiculata Blume.

\section{PENDAHULUAN}

Salah satu sumber senyawa bioaktif adalah jamur endofit. Jamur ini dapat hidup di dalam jaringan tanaman dan merupakan sumber alam yang melimpah dan dapat dijadikan sebagai sumber penemuan obat baru. Endofit mampu memproduksi senyawa yang mirip atau sama dengan senyawa yang diproduksi inangnya karena telah terjadi rekombinasi genetik antara endofit dengan inang. ${ }^{1}$
Fungi endofit memiliki kemampuan untuk memproduksi senyawa bioaktif, baik yang sama maupun tidak sama dengan inangnya tetapi seringkal memiliki aktivitas biologis yang serupa dengan senyawa bioaktif yang diproduksi inangnya. Hal ini menunjukkan senyawa bioaktif tidak hanya didapatkan pada kandungan tanaman obat saja. ${ }^{2}$ Strobel (2003), bahkan menyatakan bahwa senyawa yang dihasilkan oleh fungi endofit 
Aktivitas antibakteri ekstrak isolat fungi endofit dari akar mangrove (Rhizophora apiculata Blume) secara KLT Bioautografi.

seringkali memiliki aktivitas yang lebih besar dibandingkan aktivitas senyawa timbuh inangnya. ${ }^{2}$

Tumbuhan

mangrove

(Rhizophora apiculata Blume) sejak lama sudah diketahui mempunyai khasiat sebagai obat-obatan tradisional untuk mengobati beberapa penyakit. Penggunaan daun, buah, batang, dan akar dari mangrove telah diketahui mempunyai aktivitas antibakteri yang cukup luas. Beberapa ilmuan menyebutkan bahwa senyawa bioaktif yang terdapat dalam akar mangrove tidak selalu berasal dari tanaman mangrove itu sendiri, tetapi dapat berasal dari makhluk lain yang mensintesis bioaktif didalam bagian mangrove tersebut, berdasarkan hal ini maka dapat diduga bahwa terdapat jamur endofit yang mendiami tumbuhan tersebut dan berperan sebagai penghasil senyawa bioaktif yang memiliki aktivitas antibakteri. ${ }^{3}$ Tumbuhan mangrove memiliki kandungan senyawa aktif diantaranya saponin, flavonoid, dan tanin. Senyawa aktif ini memiliki kemampuan sebagai anti bakteri. ${ }^{3}$

Berdasarkan penelitian sebelumnya mengenai pengujian fungi endofit dari daun mangrove (Rhizophora apiculata Blume) terhadap bakteri $S$. aures dan $E$. coli dengan menggunakan metode difusi agar diperoleh hasil yang menunjukkan adanya aktivitas antibakteri ${ }^{4}$, sehingga perlu dilakukan penelitian mengenai aktivitas antibakteri ekstrak isolat fungi endofit yang berasal dari akar tumbuhan mangrove (Rhizophora apiculata Blume) dengan menggunakan metode KLT Bioautografi. Metode KLT Bioautografi digunakan karena mampu mendeteksi adanya senyawa antimikroba karena letak bercak dapat ditentukan walaupun berada dalam campuran yang kompleks sehingga memungkinkan untuk mengisolasi senyawa aktif tersebut. ${ }^{5}$

\section{METODE PENELITIAN}

\section{Alat - alat yang di gunakan}

Alat-alat yang digunakan pada penelitian ini yaitu Alat-alat gelas, Otoklaf (SMIC Model YX-280 B), cawan Petri (Normax), gelas Erlenmeyer 250 dan $500 \mathrm{~mL}$ (Iwaki Pyrex), gelas kimia 250 dan 500 mL (Iwaki Pyrex), inkubator (Memmert), lampu spiritus, lampu UV 254 dan 366 $\mathrm{nm}$ (Philips), oven (Memmert), shaker, timbangan analitik (Chyo).

\section{Bahan - bahan yang di gunakan}

Bahan-bahan yang digunakan pada penelitian ini yaitu aquadest steril, etanol $70 \%$, etil asetat, lempeng $\mathrm{KLT}$, larutan $\mathrm{NaCl} 0,9 \%$, medium 
Aktivitas antibakteri ekstrak isolat fungi endofit dari akar mangrove (Rhizophora apiculata Blume) secara KLT Bioautografi.

Nutrien Agar (NA), medium Potato Dextrosa Agar (PDA), Potato Dekstrosa Broth (PDB), kloramfenikol, bakteri uji Basillus subtilis ATCC 6633, Escherichia coli ATCC 35218, Pseudomonas aeruginosa ATCC 27853, Salmonella thyposa NCTC 786, Shigella dysentriae, Staphylococcus aureus ATCC 25923, streptococcus mutans, Vibrio cholerae dan sampel akar tumbuhan mangrove (Rhizophora apiculata Blume).

\section{Prosedur penelitian}

\section{Penyiapan sampel}

Sampel penelitian yang digunakan berupa akar mangrove. Sampel yang dikumpulkan dibersihkan dan dicuci dengan air mengalir, akar mangrove (Rhizophora apiculata Blume) yang segar dicuci dengan air mengalir guna menghilangkan tanah dan kotoran yang menempel. Selanjutnya didesinfeksi permukaan akar mangrove menggunakan etanol $70 \%$ selama 2 menit, kemudian dibilas dengan aquadest steril sebanyak 3 kali masing-masing selama 1 menit. $^{4}$

\section{Isolasi fungi endofit}

Akar mangrove dipotong kecilkecil menjadi $\pm 2 \mathrm{~cm}$. Potongan kecil akar mangrove tersebut diletakkan diatas medium Potato Dekstrosa Broth Chloramphenicol (PDAC) didalam cawan petri steril yang kemudian diinkubasi pada suhu $25^{\circ} \mathrm{C}-30^{\circ} \mathrm{C}$ selama 3 hari. Setelah 3-5 hari fungi yang tumbuh, kemudian diisolasi dan dimurnikan pada medium Potato Dekstrosa Broth (PDA) yang baru. Selama pekerjaan dilakukan secara aseptis didalam Laminar Air Flow (LAF). ${ }^{6}$

\section{Pemurnian dan Makroskopik}

Permurnian dilakukan dengan cara pemindahan masing-masing isolat fungi ke media Potato Dekstrosa Broth (PDA) yang baru, kemudian diinkubasi selama 3-5 hari pada suhu kamar. Pemurnian dilakukan sampai diperoleh isolat fungi murni yang tunggal dan dilakukan analisis secara makroskopik untuk membedakan isolat fungi yang murni. $^{7}$

\section{Uji skrining aktivitas antibakteri}

Semua isolat dari fungi endofit akar mangrove ditumbuhkan kedalam medium Potato Dekstrosa Broth (PDA), kemudian isolat fungi endofit dipotong kecil $\pm 1 \mathrm{~cm}$, ditempatkan dipermukaan medium NA yang telah berisi bakteri uji. Selanjutnya diinkubasi $1 \times 24$ jam pada suhu $37^{\circ} \mathrm{C}$. Masing-masing isolat diamati kemampuannya dalam menghambat bakteri uji yang ditandai terbentuknya zona bening. ${ }^{6}$ 
Aktivitas antibakteri ekstrak isolat fungi endofit dari akar mangrove (Rhizophora apiculata Blume) secara KLT Bioautografi.

\section{Fermentasi isolate}

Fungi endofit yang memberikan aktivitas terbesar sebagai isolat terpilih selanjutnya ditumbuhkan pada media PDA, kemudian jamur yang tumbuh dipotong ` $1,5 \mathrm{~cm} \times 1,5 \mathrm{~cm}$ dengan ose bulat lalu dimasukkan ke dalam erlenmeyer $250 \mathrm{~mL}$ yang berisi 100 $\mathrm{mL}$ media PDB untuk fermentasi. Fermentasi secara dinamis menggunakan shaker dengan

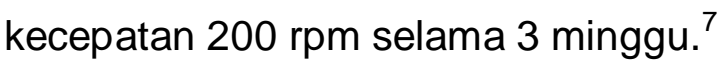

\section{Ekstrak isolate}

Setelah 3 minggu hasil fermentasi disaring untuk memisahkan supernatan dan miselia. Supernatan di ekstraksi 2 kali dengan pelarut etil asetat sedangkan miselia di maserasi selama 24 jam dengan pelarut etil asetat. Pelarut diuapkan sampai diperoleh ekstrak kering. ${ }^{7}$

Identifikasi Kromatografi Lapis Tipis (KLT)

Lempeng KLT sebelum digunakan diaktifkan terlebih dahulu dengan pemanasan dalam oven pada suhu $100^{\circ} \mathrm{C}$ selama 30 menit sebelum digunakan. Fermentat dilarutkan dengan pelarut etil asetat kemudian ditotolkan pada lempeng KLT ukuran $7 \times 1 \mathrm{~cm}$ menggunakan pipa kapiler.
Kemudian dielusi dengan menggunakan cairan pengelusi $n$ butanol : asam asetat : air dengan perbandingan 8:1:2 dan lempeng di masukkan kedalam chamber. Lempeng dikeluarkan dari chamber dan diangin-anginkan sehingga cairan pengelusinya menguap. Kemudian kromatogram yang dihasilkan diamati nodanya dibawah sinar UV pada panjang gelombang $254 \mathrm{~nm}$ dan 366 $\mathrm{nm}{ }^{6}$

\section{Pengujian secara KLT-Bioautografi}

Hasil identifikasi

$\mathrm{KLT}$ menggunakan eluen $\mathrm{n}$-butanol : asam asetat : air (8:1:2) dilanjutkan dengan uji KLT-Bioautografi dengan cara kedalam cawan petri dituang NA sebanyak $10 \mathrm{~mL}$ dan ditambahkan suspensi bakteri sebanyak $20 \mu \mathrm{L}$ lalu dihomogenkan, lempeng $\mathrm{KLT}$ yang telah dielusi diletakkan diatas permukaan medium agar yang telah diinokulasikan dengan mikroba uji kemudian dibiarkan selama 60 menit. Setelah itu lempeng diangkat dan dikeluarkan, selanjutnya diinkubasi selama $1 \times 24$ jam pada suhu $37^{\circ} \mathrm{C}$ kemudian diamati bercak yang memberikan aktivitas penghamabatan terhadap pertumbuhan bakteri uji. ${ }^{8}$ 
Aktivitas antibakteri ekstrak isolat fungi endofit dari akar mangrove (Rhizophora apiculata Blume) secara KLT Bioautografi.

\section{HASIL PENELITIAN}

Tabel 1. Hasil uji aktivitas antibakteri fermentat supernatan isolat jamur endofit akar mangrove IJAM 2.

\begin{tabular}{|c|c|c|c|}
\hline No & $\begin{array}{c}\text { Nilai } \\
\text { Rf }\end{array}$ & $\begin{array}{c}\text { Warna pada penampak bercak } \\
\text { UV } 366 \mathrm{~nm}\end{array}$ & Kode bakteri Uji aktif \\
\hline 1 & $\begin{array}{l}0,89 \\
0,72\end{array}$ & Biru Berpendar & S. dysentriae \\
\hline 2 & $\begin{array}{l}0,72 \\
0,60 \\
0,91\end{array}$ & Biru Berpendar & S. aureus \\
\hline 3 & $\begin{array}{l}0,70 \\
0,61\end{array}$ & Biru Berpendar & S. typhi \\
\hline 4 & $\begin{array}{l}0,70 \\
0,58\end{array}$ & Biru Berpendar & P. aeruginosa \\
\hline 5 & $\begin{array}{l}0,74 \\
0,61\end{array}$ & Biru Berpendar & V. cholerae \\
\hline
\end{tabular}

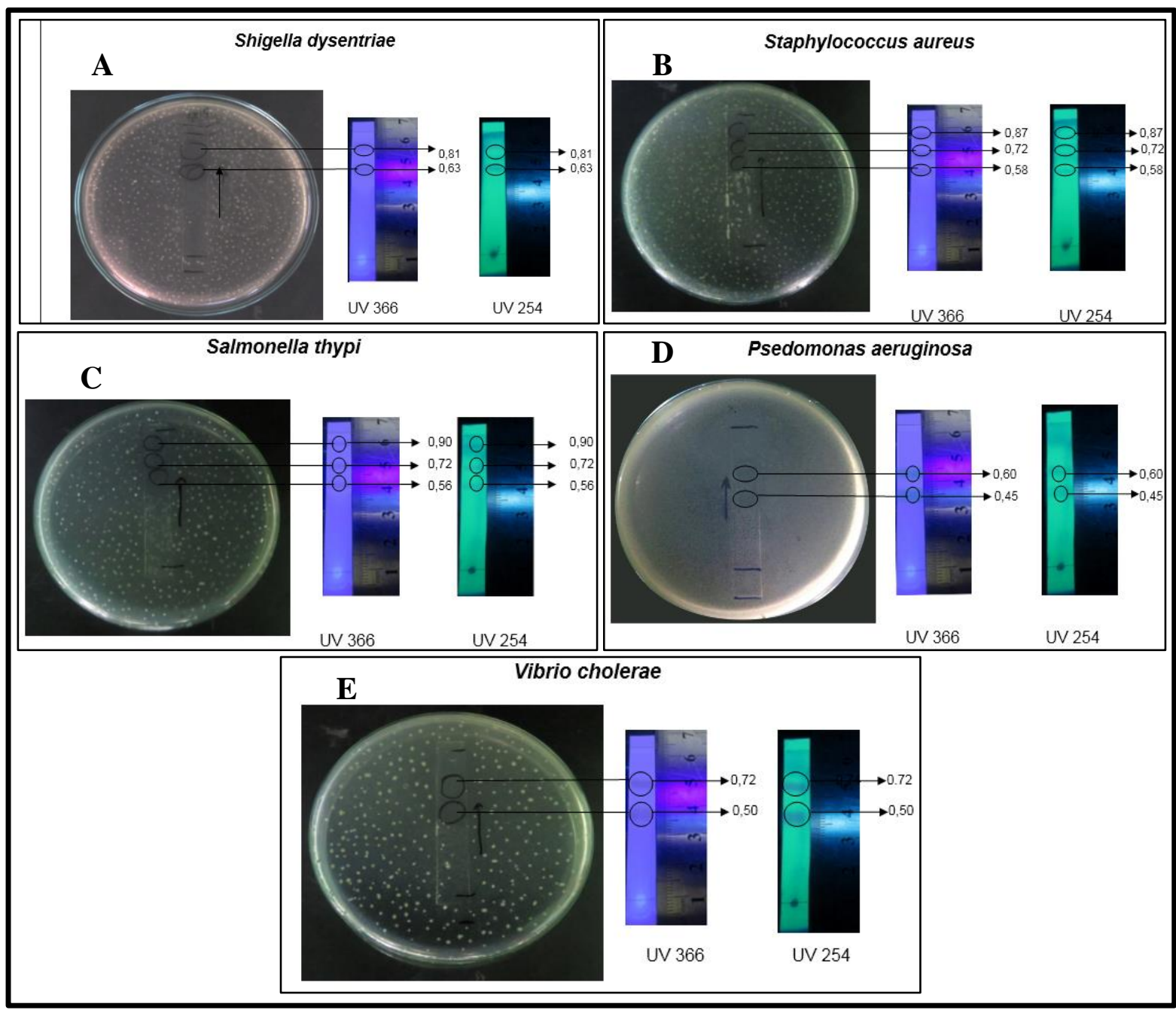

Gambar 1. Foto hasil uji KLT-Bioautografi ekstrak fermentat supernatan Isolat IJAM 2 jamur endofit pada akar mangrove (Rhizophora apiculata Blume). Gambar 1A. Shigella dysentriae. Gambar 1B. Staphylococcus aureus. Gambar 1C. Salmonella thypi. Gambar 1D. Pseudomonas aeruginosa. Gambar 1E. Vibrio cholerea. 
Aktivitas antibakteri ekstrak isolat fungi endofit dari akar mangrove (Rhizophora apiculata Blume) secara KLT Bioautografi.

Tabel 2. Hasil uji aktivitas antibakteri fertmentat miselia isolat jamur endofit akar mangrove IJAM 2.

\begin{tabular}{|c|c|c|c|}
\hline No & $\begin{array}{c}\text { Nilai } \\
\text { Rf }\end{array}$ & $\begin{array}{c}\text { Warna pada penampak bercak } \\
\text { UV } 254 \mathrm{~nm}\end{array}$ & $\begin{array}{l}\text { Kode bakteri } \\
\text { Uji aktif }\end{array}$ \\
\hline 1 & $\begin{array}{l}0,90 \\
0,74 \\
0,85\end{array}$ & Biru & S. dysentriae \\
\hline 2 & $\begin{array}{l}0,72 \\
0,61\end{array}$ & Biru & S. aureus \\
\hline 3 & $\begin{array}{l}0,72 \\
0,54\end{array}$ & Biru & S. typhi \\
\hline 4 & $\begin{array}{l}0,70 \\
0,60\end{array}$ & Biru & P. aeruginosa \\
\hline 5 & $\begin{array}{l}0,72 \\
0,61\end{array}$ & Biru & V. Cholerae \\
\hline
\end{tabular}
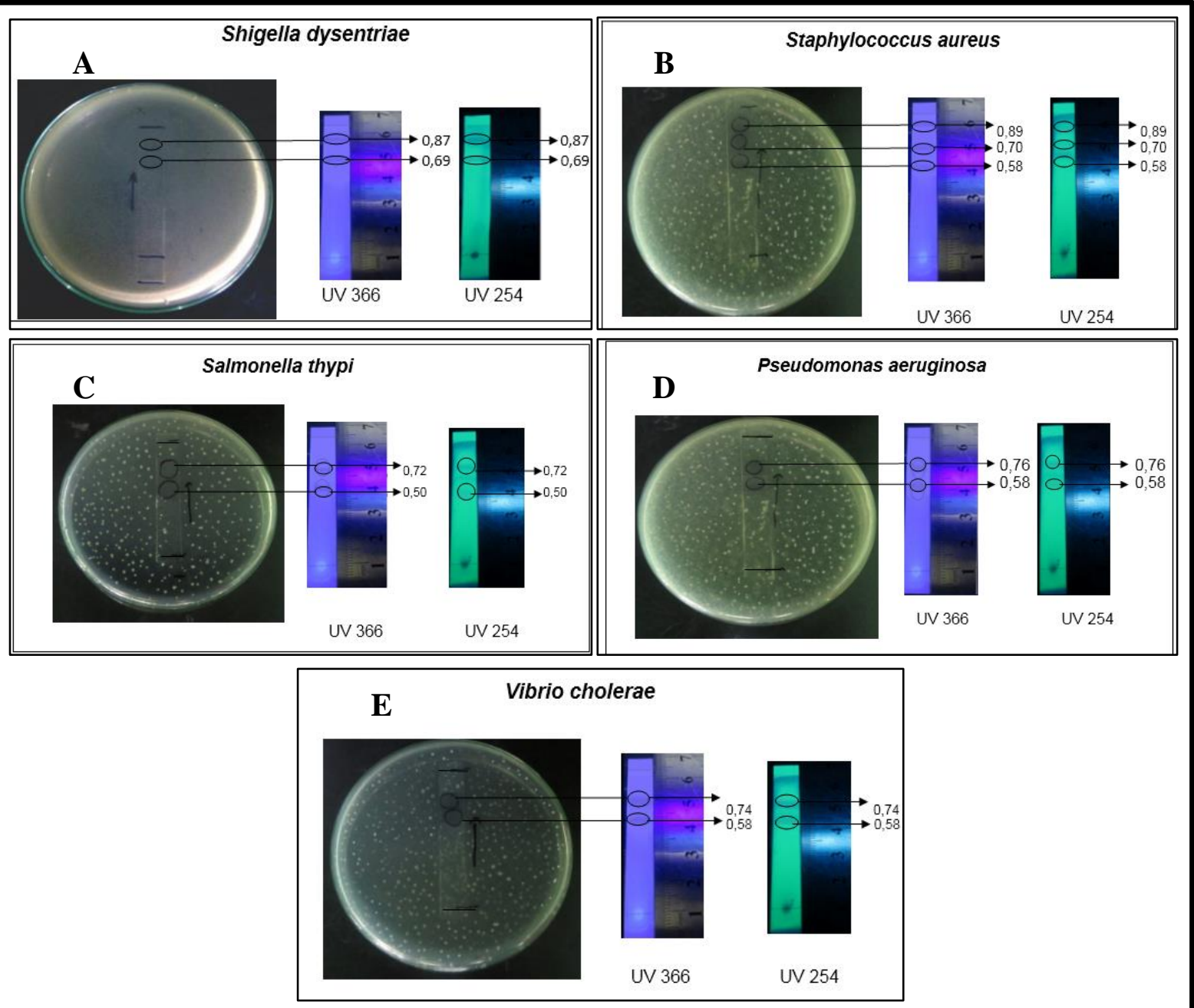

Gambar 2. Foto hasil uji KLT-Bioautografi ekstrak fermentat miselia Isolat IJAM 2 jamur endofit pada akar mangrove (Rhizophora apiculata Blume). Gambar 2A. Shigella dysentriae. Gambar 2B. Staphylococcus aureus. Gambar 2C. Salmonella thypi. Gambar 2D. Pseudomonas aeruginosa. Gambar 2E. Vibrio cholerea. 
Aktivitas antibakteri ekstrak isolat fungi endofit dari akar mangrove (Rhizophora apiculata Blume) secara KLT Bioautografi.

PEMBAHASAN

Penelitian ini sampel yang digunakan adalah jamur endofit dari akar tumbuhan mangrove yang telah di determinasi di Laboratorium Farmakognosi-Fitokimia, Fakultas Farmasi UMI Makassar dengan hasil determinasi tumbuhan akar mangrove berjenis Rhizophora apicuata Blume.

$\begin{array}{rrr}\text { Sampel akar mangrove } & \text { mizophora } \\ \text { (Rhizota } & \text { Blume) }\end{array}$
didesinfeksi menggunakan etanol $70 \%$. Alasan di gunakan etanol $70 \%$ karena etanol lebih efektif pada konsentrasi $70 \%$ daripada konsentrasi yang lebih tinggi, molekul air harus ada agar etanol dapat bekerja karena cara kerjanya dengan mengkoagulasi protein, itulah pentingnya air untuk koagulasi. Oleh sebab itu campuran etanol $70 \%$ dapat menembus lebih dalam untuk desinfeksi karena memiliki 30\% kandungan air. ${ }^{9}$

Isolasi fungi endofit pada akar mangrove (Rhizophora apiculata Blume) dengan menggunakan medium Potato Dextrosa Agar Chloramfenikol (PDAC), dimana PDA (Potato Dextrosa Agar) memiliki sumber karbohidrat, dan dextrosa sebagai sumber karbon untuk menunjang pertumbuhan jamur endofit. Adapun tujuan ditambahkan Chloramfenikol ini agar mencegah pertumbuhan dari bakteri pada medium sehingga hanya didapatkan jamur yang akan tumbuh. ${ }^{10}$

Isolat yang diperoleh selanjutnya dilakukan pemurnian yang bertujuan untuk mendapatkan kultur murni dari masing masing isolat, pemurnian ini menggunakan metode tusuk dengan cara ujung ose yang di ujungnya terdapat isolat, sampai ditemukan kultur murni. Kultur murni adalah kultur yang terdiri dari sel yang sama bentuk dan ukurannya. ${ }^{11}$

Pengujian makroskopik adalah pengujian yang dilakukan dengan tujuan untuk melihat bentuk morfologi dari masing-masing isolat jamur endofit mulai dari warna, permukaan koloni, bentuk, tepi dan elevasinya. Dari hasil pengamatan yang dilakukan setiap isolat ada yang memiliki karakteristik yang berbeda dan ada yang memiliki karakteristik yang sama. Setelah pengujian makroskopik dari 11 isolat diperoleh 6 isolat yang akan di lanjutkan ke penelitian selanjutnya karena memiliki karakteristik jamur yang sama.

Isolat yang diperoleh dilakukan pengujian skrining terhadap Bacillus subtilis, Escherichia coli, Pseudomonas aeroginosa, Staphylococcus aureus, Shigella 
Aktivitas antibakteri ekstrak isolat fungi endofit dari akar mangrove (Rhizophora apiculata Blume) secara KLT Bioautografi.

dysenteriae, Streptococcus mutans, Salmonella typhi, Vibrio cholereae.

Berdasarkan hasil pengujian skrining isolat fungi endofit dari akar tumbuhan mangrove terhadap bakteri uji diperoleh isolat fungi endofit dengan kode IJAM 2 memberikan aktivitas tertinggi terhadap 5 bakteri uji yaitu Escherichia coli, Pseudomonas aeroginosa, Staphylococcus aureus, Shigella dysenteriae, Streptococcus mutans, Salmonella typhi, Vibrio cholereae yang dibandingkan dengan klasifikasi respon hambat pertumbuhan bakteri jika diameter zona bening $>20 \mathrm{~mm}=$ kuat, $16-20$ $\mathrm{mm}$ = sedang, $10-15 \mathrm{~mm}$ = lemah, dan $<10 \mathrm{~mm}=$ tidak ada. $^{12}$

Isolat murni dengan kode IJAM 2 kemudian dilanjutkan dengan proses fermentasi dalam medium Potato Dekstrose Broth (PDB) , selama 21 minggu, sambil dishaker dengan kecepatan 200 rpm, dimana pada kecepatan ini diharapkan proses fermentasi jamurnya dapat mencapai fase stationer dan menghasilkan metabolit sekunder. ${ }^{13}$

Hasil fermentasi kemudian di ekstaksi menggunakan pelarut etil asetat dengan metode ekstraksi caircair pada supernatan dan diperoleh ekstrak supernatan, tujuan pemilihan metode tersebut karena supernatan bersifat cair dan senyawa kimia yang akan ditarik pada supernatan berada pada larutannya. Sedangkan miselia di ekstraksi menggunakan metode maserasi dan diperoleh ekstrak miselia. Hasil fermentasi kemudian di lanjutkan untuk pengujian aktivitas antibakteri terhadap beberapa mikroba uji yang bertujuan untuk melihat isolat IJAM 2 yang memiliki potensi sebagai antibakteri. Isolat IJAM2 dilarutkan menggunakan pelarut etanol dikarena etanol merupakan salah satu pelarut semi polar yang dapat menarik senyawa nonpolar hingga polar. ${ }^{8}$

Hasil identifikasi dengan profil KLT dengan menggunakan fase gerak n-butanol : asam asetat : air (8:1:2) hal ini dikarenakan masing-masing pelarut memiliki kepolaran yang berbeda dapat terpisahkan dengan eluen tersebut dan diperoleh bercak dan zona hambat dalam menghambat pertumbuhan bakteri uji. Hasil pengujian secara KLT-Bioautografi untuk fermentat supernatan diperoleh nilai Rf 0,89 dan 0,72 aktif terhadap bakteri Shigella dysentriae, nilai $\mathrm{Rf}$ 0,90 : 0,72 dan 0,60 aktif terhadap bakteri Staphylococcus aureus, nilai Rf 0,91: 0,70 dan 0,61 aktif terhadap bakteri Salmonella typi, nilai Rf 0,70 dan 0,58 aktif terhadap bakteri Pseudomonas aeroginosa, nilai $\mathrm{Rf}$ 
Aktivitas antibakteri ekstrak isolat fungi endofit dari akar mangrove (Rhizophora apiculata Blume) secara KLT Bioautografi.

0,74 dan 0,61 aktif terhadap bakteri Vibrio cholerae dapat dilihat pada tabel 1 dan gambar 1.

Sedangkan hasil pengujian secara KLT-Bioautografi untuk fermentat miselia diperoleh nilai $\mathrm{Rf}$ 0,90 dan 0,74 aktif terhadap bakteri uji Shigella dysentriae, nilai Rf $0,85: 0,72$ dan 0,61 aktif terhadap bakteri uji Staphylococcus aureus, nilai $\mathrm{Rf} 0,72$ dan 0,54 aktif terhadap bakteri uji Salmonella typi, nilai Rf 0,70 dan 0,60 aktif terhadap bakteri uji Pseudomonas aeroginosa, nilai $\mathrm{Rf} 0,72$ dan 0,61 aktif terhadap bakteri Vibrio cholerae $s$ (dapat dilihat pada gambar 13, 14, $15,16,17$, dan 18 ) dapat dilihat pada tabel 2 dan gambar 2. Ini membuktikan bahwa isolat fungi endofit dari akar mangrove (Rhizophora apiculata Blume) berpotensi sebagai antibakteri.

\section{KESIMPULAN}

Bakteri uji yang dihambat dari fermentat isolat fungi endofit pada akar mangrove (Rhizophora apiculata Blume) IJAM 2 adalah Shigella dysentriae, Staphylococcus aureus, Salmonella typi, Pseudomonas aeruginosa, dan Vibrio cholera. Profil kromatogram aktivitas antibakteri ekstrak fermentat isolat fungi endofit akar mangrove secara KLTBioautografi di peroleh bioautografi dengan bercak aktif ekstrak fermentat supernatan dan ekstrak fermentat miselia aktif memiliki aktivitas sebagai antibakteri.

\section{DAFTAR PUSTAKA}

1. Strobel GA, Daisy B. Bioprospecting for Microbial Endophytes and Their Natural Products. Microbiology and Molecular Biology Reviews 2003.67:491-502.

2. Prihatiningtias $W M$ dan Sri $W$. Aktivitas Antibakteri Fungi Endofit dari Thievalia polygonoperda, Isolat dari Tumbuhan Akar Kuning (Fibraurea chloroleuca Miers). Majalah Obat Tradisional 2011;16.

3. Ananda $\mathrm{K}$ and Sridhar $\mathrm{KR}$. Diversity of endophytic fungi in the roots of mangrove species on west coast of India. Can J Of Microb 2002;48: 871-878.

4. Dwilestari. Uji Antibakteri Jamur Endofit Pada Daun Mangrove (Sonneratia alba) Terhadap Bakteri Uji Staphylococcus aureus Dan Escherichia coli (Skripsi). Manado : Jurusan Kedokteran Universitas Sam Ratulangi, 2015.

5. Pratiwi ST. Mikrobiologi Farmasi. Yogyakarta: Penerbit Erlangga, 2008.

6. Rante $\mathrm{H}$, Taebe $\mathrm{B}$, dan Intan S. Isolasi Fungi Endofit Penghasil Senyawa Antimikroba Dari Daun Cabai Katokkon (Capsicum Annuum L Var. Chinensis) Dan Profil KLT Bioautografi. Majalah Farmasi dan Farmakologi 2013; 17(2):39-45.

7. Kjer JA, Debbab HA, Aly, and Proksch., Methods for isolation of marine-derived endophytic fungi 
Aktivitas antibakteri ekstrak isolat fungi endofit dari akar mangrove (Rhizophora apiculata Blume) secara KLT Bioautografi.

and their bioactive secondary products. Nature Publishing Group 2010.

8. Mustary M, Djide MN, Mahmud I, Hasyim N. Uji Daya Hambat dan Analisis KLT-Bioautografi Perasan Buah Sawo Manila (Achras Zapota Linn) Terhadap Bakteri Uji Salmonella Thyposa. Jurnal MKMI 2011;17(1): 25-27.

9. Mozer H. Uji Aktivitas Antifungi Ekstrak etanol 96\% Kulit Batang Kayu Jawa (Lannea coromandelica) Terhadap Aspergillus niger, Candida albicans, dan Trichophyton rubrum. Jakarta: Fakultas kedokteran dan IImu Kesehatan, Fakultas Farmasi, 2015.
10.Pelczar MJ, dan Chan. DasarDasar Mikrobiologi. Jakarta: UI Press., 2010.

11. Winarni D. Diktat Teknik Fermentasi. Surabaya: Program Studi D3 Teknik Kimia FTI-ITS, 1997.

12. Greenwood. Antibiotics Susceptibility (sensitivity) Test, Antimicrobial And Chemothraphy. USA : Mc Graw Hill Company, 1995.

13. Salle AJ. Fundamental Principle of Bacteriologi 5th Edition. New York: MC Graw Hill Book Company Inc., 1961. 